\title{
The agricultural impasse: creating "normal" post-war development in Northern Sierra Leone
}

\author{
Catherine Bolten ${ }^{1}$ \\ University of Michigan, USA
}

\section{Introduction}

The ten-year civil war that raged in Sierra Leone from 1991 to 2001 had devastating consequences: individuals suffered sexual abuse and amputation, thousands of people were driven from their homes, their children kidnapped and used as slave labor in the mines and rebel camps, and a generation of young people were "lost," ${ }^{2}$ to a mindset of survival through violence and coercion (see I. Abdullah 1998; L. Gberie 2003 ; D. Hoffman 2003; P. Richards 1996). In contemporary post-war context, the post-war contexts, reconstruction is undertaken by international non-governmental organizations (INGOs) and national governments, whose task is to repair the damage done by the war: to reintegrate combatants, repatriate refugees, feed the hungry, tend to the sick. Such was the situation in Sierra Leone, which needed aid programs to help mend the damage wrought by the war. However, what is in question is the competing visions - of local people, the national government, and aid organizations - of the direction this mending should take, whether these visions resonate with each other, and even whether they could lead to the desired effect of "normal" life in Sierra Leone. Indeed, just what is a "normal" life?

Michael Warner distinguished between a "statistical" and "evaluative" normal: that which is and that which ought to be (1999: 54). In the rush to rebuild war-torn countries, a statistical normal is the goal. Simply put, for donors faced with addressing the needs of starving people, shattered infrastructure, and battered economies, the task of rebuilding a nation after a war is not the task of fulfilling every dream and wish of the people. Rather it is to address the basic needs that dictate whether or not, on a day-to-day basis, people will most likely survive, a government will most likely be able to govern, and agriculture and markets can be given a first nudge towards operability. In Sierra Leone, President Tejan Kabbah (a former United Nations diplomat) took the opportunity, while he had the world's attention during the reconstruction of the country, to adopt resolutions - universal education, rights of children, food security. The aim was to make the country more attractive to further donations, and signal the direction of what ought to be. However, he provided neither financial backing nor concrete plans, and his resolutions served only to impose additional burdens on people still struggling to meet basic needs under the livelihood support programs established by donors. What resulted in the town of Makeni, the site of my research between 2003 and 2006, was that post-war development ground to a virtual standstill because there was no single achievable vision of what Sierra Leone should be. "Normal" is a tricky concept indeed.

Immediately after the war, living conditions in and around Makeni, the capital of the Northern Province, were dire. The rebel Revolutionary United Front (RUF) had invaded the town in 1998, and instead of burning it to the ground as they had done many others, commanders decided to use Makeni as their forward operating base. Residents suffered occupation by the RUF for three years, and aid organizations arrived in a post-war town that was in desperate need of assistance. Occupation by the RUF had left the markets bereft of basic food items, aside from their small wartime trade in basic goods which people purchased at a premium. Farmers, who had abandoned their fields for fear of being caught by rebels eager to steal food or impress them into labor, returned to find their land overgrown, tools missing or broken, and the seed stock on which they depended decimated by hungry combatants. Securing food was central in people's minds, and my interlocutors placed great faith in former President Tejan Kabbah's promise, repeated over several radio broadcasts in 2002 and 2003, that the country would achieve food security_and even export crops once again-by $2007 . \mathrm{He}$ assured his country that the government and aid organizations were working hand-in-hand to move Sierra Leone toward a brighter future.

However, Sierra Leone was importing more rice than ever by the end of my fieldwork in 2006. Villages were failing to cooperate with agricultural programs that ignored their demands for inputs or handouts, frustrated expatriates were terminating their organizations' programs when faced with non-compliance, and the towns were brimming with semi-educated children and youth who legally could not or did not want to engage in farm labor. It was clear that the mere desire for food security did not guarantee that it would occur under the government's insistence that the country adhere to the UN Convention on the Rights of the Child (CRC). The exclusion of child labor from farms under the CRC combined with the youths' insistence that education-now

\footnotetext{
1 Ph.D student, Department of Anthropology, University of Michigan. Email: cat "at” never.com. I must thank Josiah Heyman and Tim Collins for their valuable editorial assistance during the review process. I would also like to thank Richard Fanthorpe for engaging with me in discussions on the history of Sierra Leone's "dead end kids" and their current "half-baked" manifestation, and Mamadou Diouf for an enlightening discussion on what makes a "child" a "child." I also need to thank Gillian Feeley-Harnik, Stuart Kirsch and Elisha Renne for commenting on earlier incarnations of this article. This article is part of the 2008 Eric Wolf Prize special feature, edited by Timothy Collins and Josiah Heyman.

${ }^{2}$ A word used by several people I have interviewed in Sierra Leone.
} 
compulsory-elevated them above manual labor, and the unwillingness of NGOs to flexibly respond to the desires of farmers who need to replace this lost labor. It is not a typical example of a development impasse, where powerful actors intent on creating in people a certain kind of "development" can force their ideas on their intended targets (see N. Peluso and M.J. Watts 2001: 6), even if those targets define "development"—or in this case reconstruction-in completely different ways. In fact, it is much more complex.

I argue that what has been occurring in Makeni is a chasm far more fundamental than mere opinions on what constitutes "development," rather it is a struggle to define what ought to be "normal" life. Aid organizations want to re-create the pre-war "normal" of small-scale subsistence agriculture, and farmers see this as an imposition of the highly impoverished form of farming - backbreaking, lacking in dignity, inadequately small-scale and unable to bring profit-that resulted from years of government inattention to food security and a draining of labor to the diamond fields and schoolhouses. Sierra Leone has been importing the bulk of its staple food, rice, since 1954. It was at this time that the colonial education system and alluvial diamond mining had lured enough young people eager to escape the demands of their elders away from their villages, and resulted in considerably diminished farm outputs (BNA, Box DO 195-350; K. Peters 2006: 40). Farmers argue that if the government and INGOs want to re-instate farming as it existed before the war, Sierra Leoneans will be forced to continue letting fields lie fallow and spending the bulk of their meager incomes purchasing imported rice. How did this resolute misunderstanding of resource history occur?

INGOs unwittingly assume that the "normal" that existed before the war is the desirable that should be recreated, while local people see what outsiders view as "normal" life before the war as "backward," a word my interlocutors used often when describing what life has been like in Makeni for many years. Pre-war life was not "normal" in the sense that it was a livable everyday, rather it was highly impoverished and ever deteriorating, due to factors such as outmigration for education, mining, and governmental mismanagement. Local people strive for an ought, a desirable "normal" future where everything that was missing from agriculture, for example, labor and access to health care, is introduced, creating life as it should be instead of the way it was. No one ever desires the average, the statistical "normal"; rather, they want to achieve the evaluative criteria of that which is good and desirable (M. Warner 1999: 56).

The two main obstacles to this are competitive visions of what connotes post-war "progress" in northern Sierra Leone. The first is the national government's drive to make basic education compulsory, which received great emphasis as the incoming NGOs took Sierra Leone's adoption of the 1989 United Nations Convention on the Rights of the Child as a sign that its definition of "childhood" was an existing cultural norm in the country (see D. Rosen 2007: 297). The second was the essential misrecognition of the chasm between small-scale subsistence agriculture and actual food security, which resulted in the drive to restore the pre-war "norm" based around subsistence agriculture. Instating universal education and subsistence farming would critically damage the country's current opportunity to achieve food security, but achieving neither would be a complete failure of "progress" to take hold in one of the world's poorest nations, condemning it to languish longer in poverty's grasp, perhaps sowing the seeds for future discontent, and future conflict (see J. Hanlon 2005: 466).

With the CRC, the United Nations essentially declared children ineligible to work on farms. Parents know that child labor-such as pulling weeds and scaring birds-is essential to successful farming; however with compulsory education they suffer the loss of labor and they need to pay school fees. In addition, once children have lived in town and gained some education, they view farming as backward, impoverished, and inferior to waged labor, and rarely return. Villages have lost the bulk of their laboring populations, and NGOs have entered this environment, determined to make farming "work" in these conditions, which they viewpartially because the CRC declares education a child's right and labor as child exploitation (see D. Rosen 2007: 296; S. Shepler 2005: 205)—as a "normal" state of affairs that should be recreated. In this vacuum, farmers strain to institute other ways to make farming profitable. They need to replace the lost labor, and mechanization, though it is ecologically damaging, seems the silver bullet. They also want roads, which will connect them with the outside world and perhaps provide ways for crops to flow out, and money to flow in, to the villages.

In this article I analyze the ramifications of these competing ideas of what constitutes "normal" agriculture and "normal" life in and around Makeni, Sierra Leone. I argue that "development", as it is conceived by powerful actors wielding grand ideas of what constitutes progress, not only fails to bring positive change, but actually chains local people to impoverished lives. They are deemed ill-equipped to reflexively envision and direct positive livelihood change themselves. Thus farmers dream of gaining access to food while they are farming, and tractors so that they can plow, which INGOs balk at as unreasonable and irrational demands that smack of people wanting to take undue advantage of their programs. This fruitless jockeying means that disappointed program participants have shifted their focus to the government, which they ask to provide them with unambiguous goods, like roads, that require no active commitment on their part and which they can use to their own ends. They believe the government should understand that they need "encouragement" to thrive, rather than outsiders telling them what is good for them. However, in order to gain favors from the government, they must also accept the government's insistence that they educate their children. They do so even though bitter experience has taught parents that, once educated, children do not return, especially if farming offers them only a life of backbreaking, "backward" toil with few prospects of either profit or progress. As the agricultural trajectory currently points, this is the only life on offer. 


\section{Making education compulsory: can families afford to develop?}

Brimming with enthusiasm for "progress" which accompanied the post-war aid boom, and eager to encourage further investment by proving Sierra Leone's capacity to become a developed nation, former President Kabbah announced in a radio broadcast in 2001 that primary school education was compulsory for all children. Most of my interlocutors from the farming villages around Makeni had mixed feelings about this because education requires a tremendous financial outlay, and also removes a child's labor from the family pool. In addition, parents feel that education is a financial risk with no guaranteed benefits. "I would say, 'okay' if I knew my children would find jobs afterward," said one farmer who hesitated to endorse compulsory primary education. Many feel that Kabbah was attempting to force Sierra Leoneans to "develop" the country from nothing, instead of providing the economic preconditions that would enable development by encouraging foreign businesses to come to Sierra Leone and stimulate the economy. Making schooling compulsory cost the government little, but it was certainly costly for poor farming families with many children.

\section{The paradox of field labor and educated labor: can the two co-exist?}

Youth: I come from M-village a few miles from here, and from before the war I have been to school for four years. I can read some English, I can write, I know how to do sums and subtractions. I went back to school after the war for a little bit, but then there was no money for it, so I left.

CB: What are you doing in town?

Youth: Well, I am not doing anything right now. I am looking for a job so I can get a good salary but there is nothing here yet. I will just wait for it and keep looking.

CB: Do your parents want you to go back to $\mathrm{M}$-village?

Youth: Yes they do but I do not want to go. There is nothing there for me. My parents did not go to school, they cannot even write their own names! I am the most educated in my family; I should have a real job. My parents did not pay fees so that I come back with nothing and be an illiterate nobody [i.e. a farmer]. There is no food there. At least in town I have my friends and we can always find a little something.

Many of the children enrolled in Makeni schools are from the dozens of farming villages (most comprising a hundred to two hundred people) within two miles of Makeni, and they walk to school each day. Their attendance is predicated on parents' ability to negotiate the paradox of whether they can afford-both in terms of fees and farm labor - to educate their children. Most will make the sacrifice to pay school fees for as long as they can, however the majority of them stop attending when the parents can neither find money for school fees nor afford to lose their labor in the fields. Those children who have learned to read and write often choose to remain in the urban areas looking for waged employment instead of returning to the village, further deepening the rural labor crisis and pushing the region further from food security.

Agriculture is not working around Makeni at the moment, according to one farmer, because the working population is much less than the number of dependents. Therefore any discussion about agriculture is necessarily a discussion about educational migrancy. When one walks through a village, the bulk of the population are older adults and small children, as most of the youth are either away at school or looking for opportunities in town. By making education compulsory, the government is asking farmers to remove essential child labor, such as weeding and scaring birds, from the farms. Nothing has replaced this missing labor, and harvests have suffered. Thus village farms have been left struggling: farm labor has been diverted in the name of national "development," but the "developing" nation has not replaced the missing labor.

When interviewing women in the villages, I found considerable tension in their feelings about educating their children. In bad harvest years, they must sell the entire proceeds of their small farms to send children to school. At the same time, parents must pay outside laborers in order to replace their missing children's labor, and this money is rarely available. The labor of teenage boys is especially critical, because it is the young men who perform the arduous work of clearing fields for planting. After letting fields lie fallow since farms were abandoned with the RUF invasion in 1998, no upland fields, old or new, can be planted without this first step. Since returning to their fields, women find they must replant the same swampy areas with their daughters (whom they often pull from school for those few key days or weeks) over and over, and the swampland, which is very limited in the arid north, is exhausted. This is why people are especially preoccupied with what the young men are doing.

Women viewed agriculture as a means of solidifying their children's sense of obligation towards them. The burden falls to mothers to pay school fees if they want to educate particular children past the first few years of primary school, and they need independent incomes in order to do so. In one village, a group of women started a cooperative garden after the war with some donated seeds, and each woman volunteered time to tend it. As the vegetables ripened, they were all sold in the market and the proceeds pooled to send their children to school. One year a poor harvest meant their seed stock evaporated. All the children were pulled from school, 
and they resented being brought back to the village to assist on the farms. Many refused to come home. One woman said, "the children only stay and do agriculture if they cannot find a way to leave. Poverty makes children want to leave, the lack of education means they lack opportunities." ${ }^{3}$ What the women want is to be able to control their children's futures by providing them with school fees so that they have opportunities to find employment in town, and still feel responsible towards their parents. They want "development" for their children, but loathe the possibility that the children might think that their newly acquired education, however paltry, makes them too good for village work or village life.

Most fathers I interviewed prioritized farming over school for their families. Several men said that if they could farm productively, then they could be concerned about putting their children through school, and not the other way around. Many are preoccupied with rebuilding the seed stock that was lost during the war, and have neither the money nor the surplus to sell in order to educate their children. One man thought the best compromise was bringing the town opportunities into the village;

Is there a way you can provide skilled training in the village so the children don't leave? When these kids go to secondary school there are too many constraints [financial constraints of paying school fees and room and board in town]. A secondary school here would keep them in the village, and if poyo [palm wine] tappers could earn a living here they wouldn't leave. If we had mechanical agriculture the youth wouldn't leave.

He sees that most villages outside of Makeni lack infrastructure, and serve only as agricultural outposts to towns, instead of being functioning economic nodes in their own right. This reinforces the perception that village life and farming are "backward" occupations, a perception which could be reversed if educational and other opportunities were brought to the village, instead of children having to leave to pursue them.

Once the youth leave to look for education or opportunities in town, the familial bonds disintegrate. The loss of labor means that parents cannot afford to give their children all the education they desire, and the distance and increased cost of living in an urban area means that youth in town are more impoverished than those who remain in the village. This in turn loosens the ties of obligation between youth and parents, as Krijn Peters (2006: 139) noted for children who had left their villages in southern Sierra Leone in 2004. When parents can no longer act as patrons, children are no longer bound to assist them, and now many youth live a life of poverty and freedom from parental control in the towns.

Two teachers noted this, and also said that youth do not understand that they can make money farming. Each teacher has her own farm, one a small palm plantation left to her by her late husband, the other the family farm left by her parents, which supplemented their income when salaries were late. "At the very least," said one, "if I do not get my salary this month I know I can go home and pull my cassava and groundnuts out of the ground!" The other has an agreement with poyo tappers who pay her for access to palm trees, and this money is what keeps her own children fed. They do not understand why the youth would want to sever their connections to the village, when it is from the village that they get their food and support. Adults refer to these youth, whom they deride for making ill-informed decisions based on paltry educations, as "half-baked." It is the "half-baked" youth especially who push for technological and educational changes in farming, as it will only be a socially valuable pursuit if it has "joined itself" with progress.

\section{Semi-educated youth and visions of progress}

The problem of semi-educated children preferring wage labor to farm labor has existed in Sierra Leone since colonial times. Administrators in the 1950s talked about the increasing problem of "dead end kids," school migrants from villages who, though they have completed only a little bit of schooling, reject manual labor (Fanthorpe, pers. comm., October 2006). Instead they stay in the towns and look for salaried jobs, and while they are unemployed spend their times drinking poyo, smoking marijuana, and talking politics in the town's "ghettos," its secretive back-alley hangouts where illegal activities often take place. ${ }^{4}$ They are the result of what Aidan Southall sees as the paradox of "modernity" in parts of the world where it has brought few benefits to either country or city life:

The question of whether rural-urban migrants are better off in town is not a question of whether modern life has brought improvements in traditional life-which it should and could but in the vast majority of cases has not-but whether modern urban life, even at its lowest, offers more to migrants than can the modern, oppressed, exploited, impoverished countryside. (Southall 1988: 4)

\footnotetext{
${ }^{3}$ I am paraphrasing their comments from notes that I took in Krio that were translated for me from Temne by each village's "spokesman," who was elected because he spoke Krio and/or English and could thus also communicate a village's needs to any NGO or government employee that might visit the village.

${ }^{4}$ This phenomenon is present around the world. J.D.Y. Peel noted that in Yoruba society, the youth who were not successful academically "were not prepared to live in rural society or work on farms" and instead moved to the urban areas looking for white-collar jobs (1978: 157). Papua New Guinean villagers talk about rubis youth, particularly semi-educated migrants, who do not help their villages, but instead drift from town to town, working sometimes but mostly living off friends and kin (M.F. Smith, 1994: 227). The attribution does not exist for girls, for whom the transition to adulthood is marked more gradually, with initiation and marriage, and is less dependent on their work status (see J. Cole, 2005: 894).
} 
Migrants hope that urbanization automatically means "progress." For many of these youth, the disappointment they suffer when they are unable to force progress in their lives leads to time spent conversing angrily with others in the same situation about how the government of Sierra Leone has failed them.

The phenomenon of disinterested "half-baked" youth is in large part an unforeseen consequence of the eagerness of youth deemed "war-affected" to adopt the social position and attitudes of the internationally declared "child". This designation was made by the United Nations and INGOs that received UN funding to conduct reintegration activities. This is despite Sierra Leone's own Youth Policy declaring anyone between the ages of 15 and 35 to potentially be a "youth," and thus occupying a liminal position between cultural child and cultural adult (see S. Shepler 2004: 11). "This is even though," asserts Mamadou Diouf, "if you have killed and had sex, as most young combatants had done, your community will never consider you a child!" (pers. comm., September 2004). A "child," according to the CRC, is anyone under the age of eighteen, no matter their personal history. Youth under 18 readily adopted the Optional Protocol to the CRC doctrine concerning the use of children in conflict that holds them harmless for any actions committed while juveniles. According to Susan Shepler, this meant they took on a "discourse of abdicated responsibility," namely that they did not choose to fight or commit atrocities, they were drugged, or threatened, or too young to know better (2005: 199, 205). This had the benefit of easing their reintegration into communities that had been made aware of the doctrine and were formerly suspicious of young ex-combatants, even though Shepler's informants were concerned that "troublesome boys would grow into troublesome men" (S. Shepler 2004: 33).

The drive to adopt the tenets of the CRC was almost too hasty on all sides. The national government instituted compulsory primary education as public notice of its commitment to honoring children's rights to education. Parents, complying with a government policy that promised them a better future through investment in "the leaders of tomorrow," initially sent young people to school in droves. With this apparent commitment made on the part of all others, NGOs adopted programs that were complicit in removing children completely from manual labor. No one thought to ask who would remain on the farms to perform the labor so crucial to the country's drive for food security, and no one remained that had the option of leaving.

The bulk of the INGOs in and around Makeni tasked with ex-combatant reintegration decided that anyone under the age of 18 should be sent to formal education, and those over 18 should undertake skills training. The one national NGO operating in Makeni in 2003 that actively trained "war-affected" children (either because they were combatants or had been orphaned or abandoned during the war) who did not want to go to school in skills such as tailoring and carpentry was, at the time of my first visit in 2003, constructing a permanent workshop where they could train up to a hundred children a year as artisans. The Director was confident that they would receive the rest of the funding for the project from an international donor who had promised to finish the workshop.

When I returned a year later, the NGO had closed its doors, the unfinished workshop abandoned, and all the program's children were gone. Training children in skills was not "popular" with the aid community, according to the former Director, and they had been unable to secure the necessary funding. "The just wanted us to treat the really troublesome children at the end of the war," he said, "but they did not want to do child skills training during peacetime." Even the government had failed to step in with the necessary funds. The CRC was in full force, it seems, and all children would receive formal education, in spite of the lack of economic opportunities awaiting them. The closing of this center also lends credence to Krijn Peters' argument that skills training for war-affected youth was more about distracting them from potentially pursuing violence as means to get their way in the days of tenuous peace just at war's end, than it was about actual training to promote longterm economic stability (2006: 129).

In spite of the ramifications of the CRC, the disdain that most semi-educated and unemployed youth have for farming is not a new phenomenon. Among Sierra Leone's first educated youth, the goal was to participate in the offerings of the developed world, and many intended to use their training to promote community development. Michael Jackson worked in Kabala, in northeastern Sierra Leone, in 1969 on the "mystique of literacy" and how education ultimately failed the children of farmers. Though they originally engaged zealously with education in order to "help" themselves and their country, these children found no careers with which to do anything waiting for them at the end of their schooling: ${ }^{5}$

In my interviews with school students I was struck by the poignantly impossible gulf between their dreams and their reality. Though most were the children of farmers, they showed their disdain for farming in the zeal with which they laundered their uniforms, washed their bodies, manicured their fingernails, and, at one time, wore white gloves on their hands. Thirty years have passed, but as I leaf through the tattered stacks of paper that I have lugged around the world for so long... I read of ambitions to become a doctor, a teacher, an engineer, "to help my people," "to help my parents," "to help my country," and wonder what became of these dreamers when they left school and found their hopes dashed. Of sixteen-year-old Marie Kandeh, for example, who

\footnotetext{
5 See John Nkinyangi (1991: 166) on how students for whom employment was always lacking are the most likely to engage in protests and riots against the government and educational policies.
} 
wrote: "As we all know that education today is the key of life, anyone who does not try to be educated will be just like a slave." (M. Jackson 2004: 149)

Slavery was the fate of someone chained to farming, and with no option but to do what one's parents said and did, because the mind has not been trained to reflect on more important things. Richard Fanthorpe (pers. comm., October 2006) and Krijn Peters (2004: 26-28, 2006: 40) have found that in the years leading up to the RUF war, children and youth in rural areas were effectively slaves to chiefs and other "big" people. They were subjected to forced labor, could not marry for lack of money, and lived under the thumb of the powerful. Education was, and still appears as, the enlightened exit for children who wanted greater opportunities.

What is new about the phenomenon of the "half-baked" is the notion of right over privilege. When Jackson conducted his research, the students were members of a small minority of children who felt they had gained access to better lives that others lacked, and there was a sense of responsibility attached to "help their people" in some sense. Currently, the popular notion among youth is that they are entitled to waged jobs because of their educations, hence the lack of compunction over what their elders see as them wasting their lives in town. The antagonism that defines the relationship between generations in this regard deepens the crisis.

Thirty years later, few white-collar opportunities actually exist for today's youth. They have extricated themselves from the control of elders, but with disastrous consequences for food security. No programwhether initiated by an NGO, local community organization, or national government-has yet overcome this problem of labor shortages. No NGO director that I spoke to had coherent programs or even ideas about setting up youth farming cooperatives where elders could not assert control, as all cooperative agricultural programs depended on villages donating land that they owned. No young people wanted to give up their independence in town to be treated like children again. The government rice research station outside of Makeni hired laborers on wages; most were men who had given up farming for themselves and preferred the stability of a wage.

Those farmers who argued that agriculture must come first, emphasized that agricultural educationclassroom learning that the youth could apply to working in the villages-would return dignity to farming. One friend of mine, who founded a community-based agricultural organization, pointed out that the main reason the youth see farmers as "backward" is because they cannot feed themselves, therefore they cannot know much:

Sierra Leone farmers are the poorest people [in the country]. So just imagine, something is wrong somewhere. And it is not as if [the farmer] is not farming, he is farming every year! But look at him: he is at his own farm every day and he cannot feed himself. Everyday, he looks to other people to feed him. So where now can you see his qualification of being a farmer? Something is misplaced. The soil is so rich that whatsoever crop we plant in this country will do well. You see? But the management, maybe the education [is not there]. Even farmers are not educated to the level that can help them help themselves! (interview with SM)

SM, a lifelong farmer from the east, has heard farmers talked about by the youth as so backward that they have not learned through experience, and so though lifelong farmers, cannot feed themselves. The youth scoff at any "knowledge" possessed by farmers who struggle to feed their own families, whether or not they appreciate the ongoing shortages of seeds and labor. This is why youth find farming of dubious worth: Sierra Leonean farmers, using archaic means, appear totally incapable to them.

Farmers I talked to were divided over whether or not they wanted their educated children to return to their home villages. Not all parents want their children to be educated and return to the village to farm. Many argued for the benefits that can be gained when one has a child in the urban area that lives on wages, and they are torn between wanting their children to bring their education back to the village, or to prosper with it in town. The following is a translation of a conversation held in Krio, the national lingua franca, between SM, the head of the agricultural Community-Based Organization (CBO) that is attempting to promote cooperative agriculture in villages, and the members of his cooperative in one village, who are often reluctant to work on the cooperative plot because it provides them no monetary returns.

AK (woman): I want the children to go to school, and not all of them to practice farming when they are adults. Let at least a few of them go and make a life in the towns, that way I will have someone to support me in the future.

IM (man): But you cannot replace the farming in a chiefdom! There is dignity in it, especially for a chiefdom that can produce its own food.

MK (man): Yes, but if your child can get an education and get a job and release himself from the burden of working in the bush, then he should do it.

MC (village head of CBO): We can bring education back to the village. I want my children to go to school, there they will learn the modern way to do agriculture. Then they can bring this knowledge back 
to the village and teach us all here, then the village will be producing more food. And then they can return to the town and sit in an office and make money to support their parents when they are old.

SM: ${ }^{6}$ No, farming is natural work, you just need basic education to count seeds, nothing modern will help us here. If I had a farm here I would sit down there and work to feed myself, for if I am able to do this then I am a king! If I only work for wages then I am always a slave. I am a slave to the money and to my boss who gives me the money. I am at the mercy of them firing me at any moment or of the price of rice increasing, and if my wages do not increase, then what do I do? But if I am a farmer I have control over all these things and can live in dignity. A farmer can feed himself any time and doesn't have to depend on anyone else. ${ }^{7}$

AT (woman): But I still think my children should go to school. It is the only way they will help themselves tomorrow.

FK (woman): But if you go to school and learn books and just come back to the village with all of this knowledge and no food, you will still die.

The multivalent and unpredictable consequences of education make it an uncertain arm of progress for villagers. As FK said, it is possible that what they learn in the schools is useless on a farm, and then you have spent all the money on school for nothing, as the children are not able to help themselves. All of them had at least one child "doing nothing" in town, but could not coax them to return. The youth still prefer this life to village life, because at least there is a chance, however small, that business opportunities will find them (see K. Hart 1976: 492; A. Harts-Broekhuis 1997: 111-113).

A shared commitment to food security does not mean that any interested actors-youth, elders, NGOs, government-agree on the means by which it will be achieved. This clash is intimately linked to the incommensurable perspectives of what the desirable "normal" state of agriculture should be, and how it is related not just to the age-old problem of shortages of the young men who perform the necessary task of clearing and plowing fields, but to how this task will occur on an unprecedented scale. Considering that every field within a day's walking distance of Makeni was abandoned during the RUF occupation, it is no wonder that farming families are so pre-occupied with the missing male labor that would make planting possible in the first place. Every field needed this labor, not just the few that fell within the normal fallow rotation. Hence it is no surprise that farmers are struggling to make aid responsive to their needs.

\section{Defining a desirable "normal" agriculture: what are the benchmarks of progress?}

Post-war reconstruction as it has been implemented does not necessarily have national food security as a goal; as was mentioned by one ex-combatant who participated in an "agricultural reintegration program" sponsored by a foreign government and, upon his graduation from the program, received two bushels of rice seed and was expected to prosper on his own (see also K. Peters, 2006: 95). Because the working assumption is that the CRC should be as firm in practice as in name in any country that adopts it, program managers assume that farmers will be working without any child labor, even though, as Susan Shepler has argued, "Child labor almost defines childhood in Sierra Leone. A child who does not work is a bad child" (2004: 12).

Agriculture programs tend to discount completely the labor that children should provide, assuming instead that adults can replace this labor by farming cooperatively amongst themselves. But will this work when every family is trying to make enough of their own money to pay school fees? Villages are not even eligible to register for government or NGO funds if they have not registered as a cooperative CBO with the national government, and participating farmers rarely have the ready cash to educate their children for several years after banding together in order to apply for funds. They want money and seed to farm individually, and their protests to this end usually result in the termination of aid programs. The paradox seems inescapable.

"The people in these villages, they don't want the NGOs to come making all these promises and telling them what to do," FS told me, "they want to be able to take the seeds and the money and use it themselves, because maybe they trust themselves to get the farming going again more than they trust these NGO guys." Farmers are suspicious of aid organizations funded and run by foreigners who have no experience with local conditions and needs, as they want to be able to run their own farms using aid money, and need to "organize" officially in order to apply for this assistance and agree to farm cooperatively in order to receive it. Aid is needed, but the conditions set by the government in order to comply with NGO wishes are despised (see E.

\footnotetext{
$6 \mathrm{SM}$ is a committed socialist and a stranger to Makeni who holds no land rights. He bases his arguments on tenets of cooperative farming he learned during the ideology training of the RUF, when he then worked a farm for many years at the Kailahun RUF base.

SM's tirade against waged "slave" labor resonates with Gillian Feeley-Harnik's description of people in Analalalva, Madagascar, avoiding waged labor because it is "the work of purchased slaves who worked for others with little benefit to themselves" (1991: 250).
} 
Crewe and E. Harrison, 1998: 69). Individuals resent being told that they must put the specific needs of their own families aside, pool their ancestral land, and share resources with others in order to receive assistance. However, the dire need for seed stock and tools in order to re-start farming means that some people and organizations, like FS, are still willing to engage with INGOs, even as they resent being told how they must use the funds, and often struggle against the tenets set by INGOs as to what kind of farming should be created in the aftermath of war.

The critical tenet is that INGOs make false assumptions about how agriculture works, both socially and cyclically, when formulating what kinds of programs they will implement in villages, as became clear when I sat with FS and asked him about his experiences with other INGO programs in Bombali district. Instead of defining working "communities" and recreating agriculture as it existed before the war, people in villages want inputs that will allow them to correct all of the problems that occurred with farming in the past, which aside from labor include lack of fail-safe seed distribution and lack of government support to process their products and get them to market. The improvements that they desire include seeds, food, tractors, and roads.

\section{Seed stock and "food for work:" development language and ideas of working communities}

People have standing seed stocks by then [before the war] and this all went away [during the war]: no seeds. And it came to a time when farming came to a stop, abruptly, because farming should be a continuous process, no? It should be continuous. But if you just come and eat even the seedlings, at the end of the day there is no farming, so you have planted hunger. So that was the kind of thing that happened. Even the farming materials like cutlasses and hoes were destroyed. So... it means we have to start it over again. But the main problem is those seeds. Seed is food while the farmer is planting, then what does he plant? What to sustain the workers with? They didn't have anything to start with. (interview with FS)

The story that came most often from conversations about agriculture with farmers in Makeni went thus: agriculture was impoverished before the war, ceased completely during the war, farmers need assistance in order to start farming again, and this assistance should take the form of seed stocks, "food for work," and mechanization. Even though neither of the latter two existed around Makeni before the war, farmers were not ignorant of the ways that they could change farming in their community to make it not only workable, but profitable, which would allow them to adopt changes required by the government, such as sending all of their children to school. They were not going to be content with receiving a bit of seed and manual tools, as this would not solve anything that caused agriculture's decline in the past, like labor shortages, or problems that exist because of the war, like a collapsed seed stock.

Farmers were not ignorant of the Food For Work programs occurring in other areas of the country. ${ }^{8}$ The World Food Programme implemented these programs in the 1960s to provide drought relief in areas where people's daily labor did not result in an adequate supply of food. ${ }^{9}$ Farmers were set tasks, be it farming, building roads, or constructing public buildings, for which the program would pay them in food for their families. One farmer stated that they needed the continual inputs of food rations in order to farm, a need that is mutually entailed with the replenishment of seed stock.

According to FS, no one knows how long it takes to build up seed stock from nothing, as no one had ever had to do it before the war. The chief and other big men always held the main seed stock for a village, for use in times of crisis and distributed through kin networks. Even in times of localized war and drought, seed could always be found, as it was transported through distant kin networks to those who needed assistance. After a ten-year war, this is no longer the case. No one has seed in reserve, either to plant or to loan. Many of the generations-old kin networks through which seed was habitually transferred were broken up, and farmers feel that they are on their own, trying to create seed "from nothing." The farmers explained that it is a false assumption to presume that a single input of seed stock will result in sustainable farming, which was the assumption made by most INGOs who had a farming component to the assistance programs they instituted in the area after the war. This is why short-term agricultural programs failed, and why local people contest that agricultural INGOs do not really understand farming, either as it existed before the labor decline, or as it should be with few willing laborers.

\footnotetext{
${ }^{8}$ At the time of my research, several international NGOs were doing such programs in the swamp rice regions of the south and northwest in order to encourage people to undertake large-scale planting. In 2003 ex-combatants who engaged themselves in cooperative agriculture with local villages received food for work, which they often shared with their noncombatant friends. The villages themselves, however, were never formal recipients of food for work.

${ }^{9}$ I discovered during my research in Botswana, for example, continued droughts and the failure of small-scale farming and animal husbandry in the 1980s sparked the institutionalization of food for work programs. In the late 1980s the national government created a national department called Drought Relief, through which people in villages are variously employed on programs for which they receive rations of food. In one village in northern Botswana, some men had been on drought relief for ten years, regardless of whether the rains arrived.
}

Journal of Political Ecology $\quad$ Vol. 16, 2009 
One farmer explained the process. If a family is given a bag of seed rice and told to plant it, they will reserve some to eat in the meantime, as they have no other source of income, nor any food in reserve from the previous year when they perhaps lived on food aid as displaced people (as did his family). "The seed stock goes to stop the cries of your children," he responded, when I asked him what happened to his seed. They also reserve a small amount to save as next season's seed in case a bad season means no returns on this year's rice. This means much less than the whole bag is planted. Rice takes up to five months to harvest, and what is the family meant to eat in the meantime, if they do not eat some of their reserved seed stock? The family harvests their crop, and must reserve some of it to plant the next year. However, in the rainy season when it is too wet to plant, the rice harvested the previous year has run out, and the only way the family can survive is by dipping into the small reserve saved for next year's seed.

If seed stock does not exist in quantity enough to plant a full field, feed a family for the duration of the growing season, and reserve some for the following season, there is simply not enough. The only way to build up a sufficient seed stock to keep a farming family from starving is to feed them continually for several years so that they have the energy to farm, and all the seed stock is saved as seed and not eaten in the hungry times. Seed stock programs must exist in tandem with Food For Work, otherwise the seed will be eaten. It is the only way to ensure that a village that is given a bag of seed, told to plant, and left to their own devices will not eventually consume the seed because they are hungry. Farmers were angry that the INGOs called them lazy and not "development minded" when they promptly ate the seed and asked for more. More than one village in Makeni's district was cut off from post-war agricultural aid when the seed stock that was given by one or more INGOs was never planted at all.

There is, therefore, a disconnect between what INGOs want, which is harvestable crops, and what villagers need, which, aside from their desire to make farming profitable, is the energy to farm in the first place. Farmers who consumed their "development" offering because they were hungry promptly lost it, suffering accusations by their INGO providers that they were too irresponsible to run the project as it was designed. This is a problem that has been replicated all over Sierra Leone, and even strong kin networks cannot replace seed that NGOs refuse to give. The sister of one of the farmers in a village in which I worked had moved to southern Sierra Leone with her husband in 1991, and their village was devastated in the war. Once reconstruction programs were in full swing, she sent a message to her brother asking for seed because the INGO working in her village had cancelled the program when the "target" families split up the seed stock and fed their children. If he had seed to send her, he would have suffered similar accusations of disinterest in participating properly in his NGO program, so he refused.

This disconnect between the organizational idea of "community" and local understandings of networks of obligation and reciprocity is not singular to INGO workers in Sierra Leone: Stacy Pigg heard from one expatriate worker in Nepal that the main effect of any development project is an erosion of community responsibility (1997: 280; see also F. Cooper, 2001: 33). This comment was made on a project where the INGO in question had decided what the target community they were working in would look like; completely discounting supra-"community" networks or existing tensions between people in a village. Considering the importance in the past of strong familial networks ranging over immense distances to mitigate risk-like drought or plague that can affect harvests in an extremely localized way-through seed and crop sharing, the idea of a bounded "community" defined by physical proximity and thus caring in the same way as far-flung kin is absurd. In one village, people were arguing that NGOs should register families instead of artificially generated cooperatives and divide seed up accordingly, so that they could do with it as they wished: feed their children, reestablish relationships with kin elsewhere in the country, plant their own farms and send their own children to school. These bonds, and these goals, are more important than those designed by organizational necessity: namely, the necessity to better monitor progress in a bounded place. Kin networks and their management of seed would be impossible to document.

INGOs expect people in their program to act as "partners" and produce development for the "community," whereas residents, many of whom are trying to pay school fees for their children, attempt to use NGO resources to create their own visions of a desirable "normal" future. INGOs, on the other hand, do not differentiate between local ideas of "development" and the mere wasteful consumption of aid that lacks obvious benefits for a "community:" using "seed money" for food, school fees, or a distant aunt's funeral is seen as a blatant misuse of funds. This essential misrecognition of the moral modes of inputs continues to cause friction between INGOs and villagers around Makeni, and INGO workers are especially exasperated when farmers, having eaten their seed, then ask for tractors.

\section{"We need mechanization:" taking sides in arguments over how to return dignity and prosperity to farming}

The idea that tractors, or mechanization more broadly, will save agriculture was not introduced by INGOs. It originated from the long-term decline of agriculture in Sierra Leone due to labor shortages (see A. B. Zack-Williams, 1990: 23), which colonial administrators themselves blamed for the country's loss of food selfsufficiency (BNA box DO 195-122, Foreign Report 1963). The highly impoverished form of subsistence farming taking place before the war was the result of years of labor drain, strained social relationships, and 
declining output resulting from new economic opportunities in town, in mining, and in commercial logging. By insisting on cooperative agriculture as a prerequisite to mechanization, INGOs were mocking villagers' inability to provide enough agricultural labor. Farmers wanted mechanization to replace lost labor, and NGOs offered them everything else but this. One INGO worker expressed his exasperation: "how do they think they can maintain tractors when they can't tell the difference between two different types of rice? They don't need tractors, they need training!" He assumed that farmers were cloaking their laziness to do manual labor by adopting what they thought would sound "progressive" to INGO workers, which was technology transfer (see E. Crewe and E. Harrison, 1998: 91, 170).

Agriculture had already deteriorated before the war, where some families were barely able to survive, planting the same exhausted fields over and over for lack of strong young men willing to clear old fallow fields and plow them. In addition, this dissatisfaction with the critical state of farming was one of the main reasons many young people were so angry about their poverty that they were willing to join the RUF in the first place, when it first emerged in 1990 (see P. Richards, 1996: 7-8). The further draining of labor, destruction of tools and seed stocks, and bush encroachment on farms caused by ten years of war have dealt crushing blows to the already fragile remnants of agriculture in Sierra Leone. Thus does mechanization seem the ultimate solution. Consider FS's passionate plea for tractors:

The rate of food production must be increased or we will forever be clamoring for food. You see? That is why, as we are talking about the working population, most of the youth are in urban centers. Because they feel the government has not created any facility that can assist them in the rural areas, like mechanization, agriculture through mechanization. You have lots of boliland [semi-permanent swamp] here. Come with twenty or thirty tractors, put five hundred idle youth on board, have a little camp for them and give them seed. Let them stay there permanently. And you will see what will be the outcome at the end of the day.

In every conversation with farmers concerning what the main obstacle is to productive farming, the answer was usually that the tools were not there to make "a big farm" and plow all the boliland left fallow since the war, and it was only by cultivating vast tracts of land that people would consider farming profitable. It is only when farming is profitable that it is attractive to people, therefore it is the only way to coax the youth back, and the only way to guarantee food security in the country in the future, as it was in the past when big farms were made by every extended family. If big farms were to be made today, they would somehow have to come out of individual labor and bring in profits for that individual. As one man said, "people here like money, they like their own money, and if they farm it will be for themselves to make money."

The poverty driving economic habits in the area mean that people will usually choose development options that benefit themselves and their immediate family, and be beholden to only them, before thinking about the community. Gillian Feeley-Harnik discovered in Analalava, Madagascar, that people were not transplanting rice in the 1970s because they were "afraid" of the work. Farming was not only difficult, but resulted in kin asking for food from the farmer, and "pretty soon, everyone has nothing together" (1991: 204), with the individual having, as FS once said, "planted hunger."

For each individual family to "make a big farm" requires either labor, through hiring youth at a daily wage for several weeks or months to clear and plow the land manually, or hiring a tractor and operator for a day to plow a large plot of land which the women from one family can work themselves. And if a family is farming mechanically, their plot is more attractive for youth to work on, as they have "joined themselves" with progress, in the words of one young man when explaining why he would only labor on mechanized plots. ${ }^{10}$ Mechanization, it seems, is locally believed to be the silver bullet for obstacles to agricultural success, be they labor or tool shortages, immense tracts of neglected land, lack of food security, or a perceived lack of dignity in the occupation.

However, according to the town's intellectuals to whom I posed these questions, mechanization would irreparably damage agriculture. My respondents were the Paramount Chief of Bombali Sebora chiefdom, where Makeni and the bulk of the outlying villages in which I worked lie, and one of his closest friends, agronomist Dr. Foday MacBailey. Dr. MacBailey stated categorically that tractors and tractor plows are too heavy to be used profitably on either swamps or the boliland on which rice is typically grown. In rice farming, the holes made for the seedlings are less than six inches deep, and the seedlings grow small fibrous roots laterally, so they never go deep into the soil and the underlying layer of gravel, into which the water drains. When the gravel layer is intact, the soil remains aerated. In manual farming, this gravel layer remains untouched as women only dig deep enough to plant the seedling.

\footnotetext{
10 According to the IMF, the Ministry of Youth and Sports (with the assistance of the UN) has created 48 "micro-farms" around the country specifically to employ youth. However, it was not stated how many youth are employed on these farms, nor if they are mechanized or hand-worked (International Monetary Fund 2007: 46). As the IMF is also emphasizing the production of paddy (swamp) rice, (p49) and I did not hear of any of these farms while in Makeni, it is possible that none of these farms are located in the Makeni area.
} 
Tractor blades, on the other hand, cut one foot deep into the soil, where they disturb the gravel layer. People still only plant the rice six inches deep, leaving the gravel layer disturbed beneath the seedlings. The problems start during the rains, after the rice has been planted. In the torrential rains that blanket Makeni during July and August, manually planted farms do not suffer as the rain can penetrate the topsoil and drain away through the gravel. Plowed fields have space between the seedling and the gravel, and water collects in this space. What soil does not wash away, compacts into the disturbed gravel layer, making the soil essentially useless for planting rice in the next season, as any rice seedlings planted in compacted soil drown in the next heavy rain. This is true both on the perennially flooded swampland, and the seasonally flooded boliland. Even though the boliland is hard-packed soil to begin with, making it difficult to plow and making mechanization all the more attractive, continual mechanical plowing only exacerbates the problem.

The mechanics of soil disturbance are already well known to people in Bombali district, in a hard lesson learned through alluvial diamond mining. The country's most recent diamond rush took place in a town called Kamakwie, three hours drive north of Makeni and thirty miles from the Guinea border. Before diamonds were discovered in April 2004, the area was predominantly agricultural, producing mostly swamp rice. The first diamonds were discovered along the bed of the river that wends through the center of town, and so the first miners who rushed to the area concentrated on digging out the swamps, where the gravel layer could be exhumed easily in order to uncover the diamondiferous layer just beneath it. Landowners eager to earn money by leasing out their land to miners stopped cultivation and allowed youth to dig trenches in their most productive rice farming areas in their quest to benefit from the market for precious stones.

Most farming in Sella Limba chiefdom, of which Kamakwie is the capital, ceased, and food was imported. Several market women in Kamakwie lamented that as soon as the diamond rush was over, their businesses were finished because there would never be good farming in Kamakwie again, as the soil was destroyed. Even if miners filled an exhausted pit with the exhumed gravel, it would never fall into the neatly productive and aerated layers in which rice farming is possible. Seedlings planted in former mining pits would either suffocate in the compacted soil or drown in heavy rains. Where mining had occurred, agriculture was precluded. Mining in Kamakwie came to a halt less than a year after it started, and the town was still importing food when I visited the region in 2006. Most farmers eager to use tractors further south in Makeni, however, do not believe that tractor plowing would make soil unproductive in the same way as deep alluvial mining pits. Tractors seem the cure-all that would move farms past their past and current labor poverty. From this example, we can see that the violence done to the agricultural environment with mining is a result of the poverty of individuals, and it results in a spiral of impoverished people working impoverished land. There seems to be no way to break the cycle.

Dr. MacBailey went further in his condemnation of tractor farming in Sierra Leone. He stated that all the people understand is that mechanical plowing will clear a lot of land in a short period of time without requiring them to bend over and sweat, therefore it must be a sign of progress. However, they do not know that tractors were not made for high clay-content African soil, and would require more maintenance than they do in the non-tropical soils for which they were designed. He had asked people what they would do with the tractors when they are not working their own farms, and they said they would hire them out to other villages. Apparently there was no knowledge that tractors needed intensive maintenance, which he felt (perhaps a bit too harshly) people would be unwilling to undertake, were untrained to do, and that they would be unable to locate or pay for spare parts.

The price of fuel to run the tractor was also disregarded by villagers with whom he spoke. For most villagers the cost would be prohibitive. When I left Sierra Leone in April 2006, a fuel shortage had pushed the price of diesel to 11,250 leones (the local currency) per gallon (almost US\$4.00 per gallon), at a time when the average village woman selling her rice to market women earned Le4000 (US\$1.50) a day. To plow a field of several acres would cost Le100,000 in fuel alone. When Krijn Peters (2006: 96) visited an ex-combatant-led and NGO-backed agricultural project in Makeni in 2003, even with the full cooperation of all members they could not plow the land by hand in time to plant before the rains arrived. They were forced to hire a tractor to do the project's entire first year of plowing, at a cost of Le30,000 per hour (about \$13 an hour at 2003 exchange rates), plus palm wine, cigarettes, and full meals for the drivers. They had a budget provided by the national NGO HOPE Sierra Leone at the time, which had benefited from a British government grant for ex-combatant farm projects, but who would be able to pay for this now that the aid given to ex-combatants was gone?

Nonetheless the allure of tractors did not subside, because it has seized the imagination as a potential road for farmers to move past the pain and suffering of manual farming. The Paramount Chief commented that if he went to a village and asked the people what they want, and they said tractors, and he offered instead to send all of their children to agricultural school in America, they would accuse him of not wanting to help them. This is not that agricultural training was not desired, it was simply not as useful as a tractor appeared to be, as having a child away for so long was not as immediately beneficial as being able to plow a large farm and make a profit on it now.

On the other hand, SM, one of FS's fellow CBO board members, stated that no one is interested in manual farming because it is literally backbreaking, and people are not interested in suffering chronic pain or getting ill from working in the rainy season, especially since they cannot afford to walk to town to a clinic to get treatment. And there are no functioning clinics in any of the villages surrounding Makeni. In essence, poverty 
precludes manual labor because one cannot afford to get ill or injured. This fear of ill health, he says, makes them lazy. If they could farm huge plots simply by sitting on the seat of a machine, it would mean less pain and more money, and they would be more likely to engage themselves in it. They would make money, and they would not be afraid to work because they are secure knowing they have enough set aside to look after any medical problems in addition to their other basic needs. Though Dr. MacBailey contended that people's distaste for manual labor was the preeminent reason they pushed for tractors, the "laziness" described by SM, though essentially a distaste for manual labor, is also connected to the fear of the increased costs—physical, social, and economic — of manual toil.

Most of the youth who are interested in farming are those ex-combatants whose reintegration skills training was too paltry to enable them to become artisans in town, and they are adamant that mechanization is the only way they can farm profitably on other people's land. Only machines could make farms big enough that farmers could grow enough rice to not eat the next year's seed. Only machines could create large enough potential harvests to sell the surplus and save money for other things. In addition, sitting atop a tractor will show the world that they are not useless and idle--in fact, they are skilled and dignified professionals on whose shoulders rests the feeding of the nation.

According to Krijn Peters, the failure of their reintegration programs to make them productive skilled artisans was done deliberately to ensure docile unskilled labor for the mines in the east (2006: 129). But in the northern region, where mining stopped once the Kamakwie rush ended, it created a body of unskilled workers who now feel that they can only achieve personal dignity, and enough money to support their families, if they can become food security pioneers. It also created a cross-section of society willing to join themselves to any efforts to increase agricultural output, even if they have been told their preferred methods would do more harm than good. What has been doing more harm than good is that no one is willing to engage with farmers on these issues, and aid programs are cancelled left and right when farmers seem unwilling to do as they are told.

Dr. MacBailey and the Paramount Chief are both in positions of relative power vis-à-vis farmers, and from this position their criticism of local ideas about what constitutes proper "development" means they have "switched sides" in the development game (see S. Pigg, 1997: 259). Instead of agreeing with the villagers and backing up their wishes, by talking the way development professionals talk, they are seen as no longer supporting their constituents in the battle to bring development, as it is locally construed and imagined. Pigg notes that it is difficult to maintain a position as the mediating middle ground in "development" among powerful local people (p259). Though it is never vocalized in quite this way, they are forced to choose sides: either they support village claims on development, or they agree with the ideas and implementations brought from the outside. They can serve as powerful brokers for whichever side they represent, but it is always clear, just as with FS's support for mechanization, which side that is.

What all sides agree on is that agriculture would be vastly improved if more roads were built between the villages and the large towns and highways, and this is something no NGO offered. Unlike strictly structured "development" programs, roads come with no strings attached, and villagers long to be connected to a wider world that would allow them to access the "development" they actually want.

\section{No local commitment required: getting the government to build roads}

Sara Berry comments that even competent farmers, such as the Yoruba in Nigeria, need incentives and logistical support from outside their villages in order to produce food (Berry 1985: 3). In the wake of the war, many of the national NGOs that had previously provided assistance to villages, such as water wells and school buildings, never returned, as the only funding they could apply for was under the rubric of ex-combatant reintegration, and not basic village development. In the environs of Makeni, that crucial development link was replaced by the promises of the new District Council. In April 2004, people in Bombali district, in which Makeni lies, elected their first district councils in nearly thirty years. The candidates had come to the villages with many promises of development, and as the NGOs were not returning, all hopes of bringing farming back now lay with what farmers called "government encouragement." Most people with whom I spoke argued forcefully about the need for community development that the government would provide for an entire village, as at the very least, it would not create jealousy because some people were chosen as beneficiaries and others were not. It would also be more likely to reflect real needs and desires of Sierra Leoneans, rather than what Europeans thought they needed.

One form of "encouragement" mentioned repeatedly in forums was road building. Roads have been the key to development cited by Sierra Leoneans for many years, and are as much about "bringing development" as they are about encouraging village products to reach the market. When Michael Jackson was first told that roads would "bring development" to Koinadugu district in the 1960's, he found this attitude almost magical, as if people thought that the mere existence of a link to the outside world would bring the benefits of that world to them. "But it is typical of human beings everywhere that when we are mystified by a phenomenon," he wrote, "and lack the means to grasp it, we have recourse to magical thinking to provide a simulacrum of understanding and control" (2004:169). For local villagers, roads were a material connection to the outside world that they could use as they desired. And this, it seems, is all it takes for development to take its natural course and flow towards the village. 
There is little academic agreement if "development" occurs this way. James Ferguson found that roads built for development projects in Lesotho had exactly this effect, which was the opposite of what was intended. A road built from a mountainous area to the capital was meant to create an avenue for agricultural products to flow down the mountain to the urban center; instead, it created an avenue for cheap market goods to come up the valley, thus further displacing a market for local farm products (1994: 230). Gore (quoted in G. Clark, 1994: 211) found in Ghana that good road access correlated strongly with higher producer prices for farm products, because farmers with access to markets have stronger bargaining positions with lorry drivers. It is unknown what effect roads would have on Bombali's villages, except to make travel easier and thus more appealing.

Creating a path to the outside world is for young men in Bombali district a chance for them to escape village life, as much as it is a proposal for agricultural development. Young men do not feel as strongly that the roads would bring the outside world to them, as much as it would give them ways to reach the outside world themselves. As Adeline Masquelier noted, roads are modern paths to power and status for those who know how to use them, usually men (2000: 103; 2002: 836). Dorothy Hodgson confirmed this among the Maasai in Tanzania, where at one development meeting all the men argued passionately for a new road, while the women grumbled, asking "will a road feed our children and cattle?" (Hodgson 2001: 5).

Though they themselves do not move, roads are not passive development devices. They are tools most readily at the disposal of young people, who are not necessarily as invested in the farming success of their village as their elders, even though in my interviews the solution of a road was couched in the language of encouraging women in their faming activities. As Elisha Renne noted in a Yoruba town in Nigeria, it was the men who exercised the option to leave and work as wage laborers when a road was built to their town. Agricultural connections were secondary, if present at all (2003: 21). Roads would provide women with easier access to town and roadside markets, but if there are even fewer young people in the villages to help with farming, would the roads do more harm than good in the overall agricultural picture?

The result of increased access to villages would be that women have roads and transport to move their root crops (cassava and potato, farmed because they are not labor intensive) to market, and men have roads and transport through which to conduct their own business ventures, such as tree crop farming. As it stands, if a woman wants to sell her produce in town, she must carry her basket, often weighing thirty pounds (13.6 kg), several miles to the highway food market, and then compete with several dozen other women for a few meager sales. A road and transport would mean more marketing options to choose from, and quicker transport. Men argued passionately that the government needed to "open up" their villages to the rest of Sierra Leone, and that this increased contact would encourage farming, though in truth it would mainly increase their ability to interact with the wider world, and would probably have an immediately detrimental effect on farming as youth have greater opportunities to leave their villages and seek their fortunes in urban areas. Elisha Renne noted that road construction increased the "comings and goings" from a town, noting that young people could leave to seek employment, but often returned to the town to build their homes (2003: 41). The problem, noted by women, is that young people who leave Bombali's villages tend not to return. This problem notwithstanding, in our discussions the people earnestly believed that if they were just able to get the food to market, they would be able to sell it somehow, and bring the proceeds back to the village.

Roads are indeed magical: they hold the promise of a better life, and they are a form of "encouragement" from the government that is unilaterally good, with no strings attached, and no requirement that its recipients act a certain way. I found in my interviews none of the ambivalence that occurs with a long history of road building through forced labor (see M. Azavedo 1981: 5-6; A. Masquelier 2002: 829). Though in the colonial era roads many were constructed as "Chiefs' Roads" and relied on the Paramount Chief in an area to recruit and pay the laborers (BNA, box CO 267-622), the taint of the potential for increased exploitation by colonial administrators was absent. Indeed, it was the chiefs who were despised for forcing unpaid labor, and the same leaders often benefited from increased transport of goods which they could tax (see J. Alie 1990: 212). When a road was finally constructed, it meant freedom for traders to transport their goods without paying railroad cargo, and all others determined to make their fortune. For farmers living on the outskirts of Makeni, roads are a cure-all to agricultural stagnation, and the government is the best possible organization to rescue people from the backwardness they suffer partially from being isolated from the rest of the world. With roads they could have more power and options in their own lives, and this would put them in a stronger position vis-àvis outsiders, be they government officials, NGO workers, or even just middlemen looking to make quick money off of exhausted women who cannot travel the whole distance to town on foot over rough ground.

\section{Conclusions: re-conceptualizing post-war agricultural recovery}

What has been missing from analyses of post-war recovery around the world is a long historical view of "development" in an area-including consideration of agriculture, education, family and wider social structures - that would illuminate what particular vision of the world exists, and could be most effectively created. Indeed, in many places a framework of "post war creation" instead of "reconstruction" would be the most fruitful way of engaging governments, aid organizations and local people in a dialogue of a desirable world, instead of taking for granted that a recent war was the only, or the most significant, cause of suffering. While the civil war in Sierra Leone wrought devastating consequences on families, scattering or killing family 
members, destroying their property and their farms, and forcing already impoverished people to build their lives from nothing, it was hardly the most salient factor in the country's loss of agricultural production, and should not be taken as the one "abnormal" event in an otherwise "normal" historical trajectory of food production data. We can hardly blame the conflict of the 1990s in Sierra Leone for the fact that it was in 1954 that rice, the staple grain, began to be imported it in large quantities.

In addition, we cannot take for granted that the adoption of the Convention on the Rights of the Child (CRC) will unilaterally provide better lives for children, especially if the Convention was adopted amidst a flurry of aid activity. This 'adoption-under-duress' is a better signal that a government is attempting to court more international interest, or at least to offset potential donor fatigue, than it is concerned about child welfare. Valuable child labor that has historically been necessary to food production in northern Sierra Leone is drawn away from desperately needy villages that would most benefit from aid programs. And when communities are forced to form cooperatives in order to apply for aid funding, there is no way to pay school fees. In his attempt to push Sierra Leone into the modern world and encourage further investment and aid in one fell swoop, former President Tejan Kabbah did not consider the devastating consequences of his policies for delicate familial economic balances. I am concerned that other countries, in their eagerness to make themselves attractive to for aid, have adopted the CRC and are suffering increased levels of rural poverty and food insecurity.

These visions of "progress," though they may polish a country's façade for donors and make it a more politically attractive place to send aid, work in tandem to amputate the real movement toward development that people in northern Sierra Leone so desperately desire. Local people-with their insistence that mechanical farming aids would create a sustainable increase in food production-are pointing towards the absent factor in agricultural production, labor, that would not only make it possible to farm again, but possible to pay school fees, re-establish kinship ties with distant family, and make farming profitable enough to attract young people back from urban areas. If farming families could create food surpluses that they could send to the Makeni food market themselves, they could seize control of their destinies and create real "progress" that would radiate through their villages. They could return the dignity to the occupation of farming, and thus be in a much stronger position to argue for-and even pay for-their own schools and clinics. Villages would be functioning nodes of "development" in their own right, rather than starving, illiterate outposts that serve only to supply unskilled young people to the towns. A "normal" village is a place to live, not a place to flee from. Adopting this perspective on "development" can help us re-acquaint ourselves with the age-old problems not just of post-war recovery, but of rural flight in general, and perhaps shine new light on how people conceive of a desirable "normal" life.

\section{Archival sources}

\section{British National Archives (BNA) files}

Box CO 267-622

Box DO 195-122, The Economist Foreign Report. "Challenges in Sierra Leone" July 4th 1963

Box DO 195-350, Ministry of Overseas Development, London: Confidential, "The Economy of Sierra Leone, a study" June 1965

\section{References}

Abdullah, I.

1998. Bush path to destruction: the origin and character of the Revolutionary United Front/Sierra Leone. The Journal of Modern African Studies 36(2): 203-235.

Alie, J.

Azavedo, M.

1990. A new history of Sierra Leone. New York: Macmillan.

1981. The Human Price of Development: The Brazzaville Railroad and the Sara of Chad. African Berry, S. Studies Review 24(1) Mar. 1981: 1-19.

Clark, G.

1985. Fathers work for their sons: accumulation, mobility, and class formation in an extended Yoruba community. Berkeley: University of California Press.

1994. Onions are my husband: survival and accumulation by West African market women. Chicago: University of Chicago Press.

Cole, J.

2005. The jaombilo of Tamatave (Madagascar) 1992-2004: reflections on youth and globalization. The Journal of Social History 38(4): 891-914.

Cooper, F.

2001. Networks, moral discourse, and history. In Intervention and transnationalism in Africa: globallocal networks of power, eds. T.M. Callaghy, Kassimir, R. and R. Latham, 23-46. Cambridge: Cambridge University Press.

Crewe, E. and E. Harrison

1998. Whose development? An ethnography of aid. London: Zed Books. 
Feeley-Harnik, G.

1991. A green estate: restoring independence in Madagascar. Washington DC: Smithsonian Institute Press.

Ferguson, J.

1994. The Anti-politics machine: "development", depoliticization and bureaucratic power in Lesotho.

Gberie, L. Minneapolis: University of Minnesota Press.

2003. War and peace in Sierra Leone: diamonds, corruption, and the Lebanese connection. The Hanlon, J. Diamonds and Human Security Project Occasional Paper 6. Canada: Partnership Africa.

2005. Is the international community helping to recreate the preconditions for war in Sierra Leone? The Hart, K. Round Table 94(381): 459-472.

1976. The politics of unemployment in Ghana. African Affairs 75(301): 488- 497.

Harts-Broekhuis, A.

1997. How to sustain a living? Urban households and poverty in the Sahelian town of Mopti. Africa 67(1): 106-129.

Hodgson, D.L.

2001. Once Intrepid warriors: gender, ethnicity, and the cultural politics of Maasai development. Hoffman, D. Bloomington: University of Indiana Press.

2003. Like beasts in the bush: synonyms of childhood and youth in Sierra Leone. Postcolonial Studies 6(3): 295-308.

International Monetary Fund

2007. Sierra Leone: Poverty Reduction Strategy Paper-Annual Progress Report January 2007. Jackson, $\mathrm{M}$. Washington DC: IMF Publication Services.

2004. In Sierra Leone. Durham: Duke University Press.

Masquelier, A.

2000. Of Headhunters and cannibals: migrancy, labor and consumption in the Mawri imagination. Cultural Anthropology 15(1): 84-126.

Masquelier, A.

2002. Road mythographies: space, mobility, and the historical imagination in post-colonial Niger. American Ethnologist 29(4): 829-856.

Nkinyangi, J.A.

1991. Student protests in Sub-Saharan Africa. Higher Education 22(2): 157-173.

Peel, J.D.Y.

1978. Qlaju: A Yoruba concept of development. The Journal of Development Studies XIV: 135-165.

Peluso, N.L. and M.J. Watts

2001. Violent Environments. In Violent Environments, eds. N.L. Peluso and M. Watts, 3-38. Ithaca:

Peters, K. Cornell University Press.

2004. Re-examining voluntarism: youth combatants in Sierra Leone. Institute for Security Studies

Peters, K. Monograph 100. Pretoria: Institute for Security Studies

2006. Footpaths to reintegration: armed conflict, youth, and the rural crisis in Sierra Leone. Ph.D. Pigg, S.L. Dissertation, Wageningen University. Wageningen, The Netherlands.

1997. Found in most traditional societies: traditional medical practitioners between culture and development. In International development and the social sciences: essays on the history and politics of Renne, E.

knowledge, eds. F. Cooper and R. Packard, 259-290. Berkeley: Univ. of California Press.

Richards, P.

2003. Population and progress in a Yoruba Town. Ann Arbor: University of Michigan Press.

Rosen, D.

1996. Fighting for the rain forest: war, youth, and resources in Sierra Leone. Oxford: James Currey.

2007. Child soldiers, international humanitarian law, and the globalization of childhood. American Shepler, S. Anthropologist 109(2): 296-306.

2004. The social and cultural context of child soldiering in Sierra Leone. Paper for the PRIO sponsored workshop on Techniques of Violence in Civil War. Oslo, Norway, August 20-21 2004.

Shepler, S.

2005. The rites of the child: global discourses of youth and reintegrating child soldiers in Sierra Leone. Journal of Human Rights 4: 197-211. 
Smith, M.F.

1994. Hard times on Kairiru Island: poverty, development, and morality in a Papua New Guinea village. Honolulu: University of Hawaii Press.

Southall, A.

1988. Small urban centers in rural development: what else is development other than helping your own

Warner, M. home town? African Studies Review 31(3): 1-15.

1999. The Trouble with normal: sex, politics, and the ethics of queer life. New York: The Free Press.

Zack-Williams, A.B.

1990. Sierra Leone: crisis and despair. Review of African Political Economy 17(49): 22-33.

\begin{abstract}
This article analyzes the notion of "normal" post-war development in Makeni, northern Sierra Leone in light of the fact that local people, the national government, and NGOs appear to be at an impasse concerning agricultural practices. I argue that fundamentally different perspectives on what construes desirable post-war development are causing this deadlock. The government adopted the Convention on the Rights of the Child (CRC) to make the country more attractive donors (and more resistant to donor fatigue), thus making primary education compulsory and removing important child labor from farms. NGOs, believing that the government's adoption of the CRC meant that Sierra Leoneans agreed with universal education, design and fund agricultural programs from which child labor is excluded. Local people are torn between wanting their children-whom they dutifully send to school - to have a better future outside of agriculture, and needing their assistance to ensure operating farms in the present. These children, once they either finish or drop out of school, rarely return to the villages. Lacking any other means to recruit labor, farmers argue passionately that they need mechanization in order to ensure future food security, and are usually rebuffed by NGOs who call them lazy. Local people yearn for a life where they can have educated children and productive farms, and resist efforts by their government and aid organizations to "develop" their children without replacing their labor. This labor has been diminishing since diamond mining and education created alternatives to farming beginning in the 1930s. Where the international community assumes that the labor-poor, low-level subsistence farming that existed before the war is the norm that should be recreated in the aftermath, local people resist these initiatives that will only recreate the end-state of years of agricultural deterioration. Their idea of a "normal" world is one where large farms can provide farmers with the cash and surpluses they need to live in dignity.
\end{abstract}

Keywords: agriculture, education, child labor, mechanization, NGOs, Sierra Leone, Africa

\title{
Resumen
}

Este artículo analiza la noción del desarrollo "normal” después de la guerra en Makeni, al norte de Sierra Leona, considerando el hecho de que la población local, el gobierno nacional y las organizaciones no gubernamentales (ONGs) parecieran estar en un punto muerto en cuanto a las prácticas agrícolas. Yo sostengo lo que está ocasionando este punto muerto, son fundamentalmente las diferentes perspectivas sobre lo que conforma un desarrollo deseable post-guerra. El gobierno adoptó la Convención sobre los Derechos Infantiles (CRC, por sus siglas en inglés) con el fin de hacer el país más atractivo para los donadores (y más resistente a la fatiga del donante) y por consiguiente, la educación primaria se hizo obligatoria, destituyéndose la importante mano de obra infantil de los cultivos. Las ONGs, asumiendo que la adopción de la CRC por parte del gobierno, significaba que la gente de Sierra Leona estaba de acuerdo con la educación universal, diseñó y patrocinó programas agrícolas que excluían la mano de obra infantil. Los residentes locales están divididos entre el deseo de que sus hijos - a quienes tienen que enviar obligatoriamente a la escuela - tengan un mejor futuro fuera de la agricultura y la necesidad de ayuda para asegurar que los cultivos continúen hoy funcionando. Una vez que estos niños terminan o dejan la escuela, es raro que regresen a sus pueblos. A falta de otra manera para reclutar la mano de obra, los agricultores sostienen vehementemente que necesitan la mecanización con el fin de asegurar el alimento para el futuro, pero las ONGs rechazan esta propuesta llamándolos flojos. Las personas de la localidad sueñan con que sus niños cuenten algún día con educación, que sus cultivos sean productivos y con no ceder ante su gobierno y las organizaciones de asistencia que tratan de "desarrollar" a sus hijos, olvidándose de remplazar el trabajo que ellos ejercitaban. Este tipo de mano de obra ha decaído desde principios de los 30's, cuando la minería de diamantes y la educación se convirtieron en mejores alternativas que la agricultura. Donde la comunidad internacional afirma que la mejor norma a seguir en el siguiente periodo, es la agricultura de subsistencia a base de mano de obra pobre y de bajo nivel que existía antes de la guerra, los lugareños se oponen a estas iniciativas que sólo recrearían los últimos años de deterioro agrícola. La idea de un mundo "normal" es aquel donde los grandes cultivos puedan brindar a los agricultores, el dinero y los recursos necesarios para vivir dignamente.

Palabras clave: agricultura, educación, mano de obra infantil, mecanización, organizaciones no gubernamentales (ONGs), Sierra Leona, África 


\section{Résumé}

Cet article analyse la notion d'un développement après guerre « normal » dans la région de Makeni au Nord du Sierra Leone, le contexte général étant celui d'une impasse sur les pratiques agricoles à mettre en place par le gouvernement national, les ONG et la population locale. Je soutiens ici la thèse que les perspectives contradictoires des différents acteurs du développement de l'après-conflit sont à l'origine de ce blocage. Ainsi, le gouvernement a pour sa part souhaité ratifier la Convention relative aux droits de l'enfant (CRC) afin notamment de rendre le pays plus attractif aux donateurs potentiels (et donc plus résistant à ce que l'on qualifie souvent de «fatigue des donateurs »); il a dès lors rendu l'éducation primaire obligatoire et un grand nombre d'enfants qui travaillaient auparavant dans des fermes les ont de fait quitté. Les ONG, croyant ainsi que l'adoption par le gouvernement de la Convention relative aux droits de l'enfant sous-entendait que la population du Sierra Léone était d'accord avec la généralisation de l'éducation universelle, ont choisi de mettre l'accent sur le financement de programmes de développement agricole dans lequel le travail des enfants était exclu. Pour sa part, la population locale est donc écartelée entre l'envie de garantir à moyen terme à leurs enfants (qu'ils envoient régulièrement à l'école) la meilleure vie possible (en dehors du secteur agricole) et le besoin de recourir à leur aide pour exploiter ces mêmes fermes à court terme. Or, ces mêmes enfants ne reviennent que très rarement dans les fermes, une fois qu'ils ont quitté l’école, en cours d'études pour des raisons diverses ou à la fin normale de leur cycle d'études. Sans autre moyen de trouver de la main d'œuvre, les fermiers demandent donc à bénéficier d'une mécanisation de leurs outils afin de garantir la sécurité alimentaire, mais leur demande est généralement rejetée par les ONG qui les accusent d'être paresseux. De fait, la population locale rêve d'une vie où à la fois leurs enfants recevraient une éducation décente et où leurs fermes seraient productives; ils résistent donc aux efforts du gouvernement et des ONG de «développer » leurs enfants, sans leur offrir de moyen de remplacer cette main d'œuvre. Le travail dans le secteur rural diminue depuis le développement d'alternatives telles que, dès les années 1930, les mines de diamants et la création d'un système éducatif. Alors que la communauté internationale assume que l'agriculture de subsistance (non-intensive en travail) qui existait avant la guerre civile devrait être récrée, la population locale, elle, ne souhaite pas le retour à un cycle de détérioration de la place de l'agriculture dans l'économie. Leur idée d'un monde « normal » est en effet celle où de grandes exploitations agricoles permettraient aux fermiers de vivre dignement et d’épargner a minima.

Mots-clés: agriculture, éducation, travail des enfants, mécanisation, ONG, Sierra Leone, Afrique 